WIDER Working Paper 2016/20

\title{
Border adjustment mechanisms
}

Elements for economic, legal, and political analysis

Julien Bueb, ${ }^{1}$ Lilian Richieri Hanania, ${ }^{2}$ and Alice Le Clézio ${ }^{3}$

April 2016 
Abstract: This paper examines, from a multidisciplinary perspective, plausible hypotheses for implementation of border carbon adjustment mechanisms, seen as a complement to strong environmental regulation. It highlights economic, legal, and political difficulties raised by border carbon adjustments. After thoroughly reviewing their economic practicability, it analyses these mechanisms from an International Trade Law perspective, particularly vis-à-vis the General Agreement on Tariffs and Trade, sustainable development, and the principle of shared but differentiated responsibilities. It concludes with an assessment of policy-related implications of such mechanisms and outlines, in particular, how border carbon adjustments may be used as an engine of economic and energy transition, for developed and developing countries equally.

Keywords: environmental regulation, border carbon adjustment, international trade law, General Agreement on Tariffs and Trade, sustainable development, political economy

JEL classification: F64, K33, Q48, Q56

Acknowledgements: The thoughts and opinions expressed here are those of the individual contributors alone and do not necessarily reflect the views of their employers. The work was supported in part by the CEST (Centro de Estudos Sociedade e Tecnologia), University of São Paulo, Brazil.

\footnotetext{
${ }^{1}$ Centre d'analyse, de prévision et de stratégie, the University of Paris and University of Franche-Comté, Paris and Besançon, France, corresponding author: bueb.julien@gmail.com; ${ }^{2}$ Centre for Studies on Society and Technology (CEST), University of São Paulo, Brazil, the IREDIES and the CUREJ, Paris and Rouen, France; ${ }^{3}$ Centre de Recherches Internationales, Paris, France.

This study has been prepared within the UNU-WIDER project on 'The Political Economy of Clean Energy Transitions'.
}

Copyright (C) UNU-WIDER 2016

Information and requests: publications@wider.unu.edu

ISSN 1798-7237 ISBN 978-92-9256-063-8

Typescript prepared by Leslie O’Brien.

The United Nations University World Institute for Development Economics Research provides economic analysis and policy advice with the aim of promoting sustainable and equitable development. The Institute began operations in 1985 in Helsinki, Finland, as the first research and training centre of the United Nations University. Today it is a unique blend of think tank, research institute, and UN agency—providing a range of services from policy advice to governments as well as freely available original research.

The Institute is funded through income from an endowment fund with additional contributions to its work programme from Denmark, Finland, Sweden, and the United Kingdom.

Katajanokanlaituri 6 B, 00160 Helsinki, Finland

The views expressed in this paper are those of the author(s), and do not necessarily reflect the views of the Institute or the United Nations University, nor the programme/project donors. 
The recent Paris COP21 summit (30 November through 12 December 2015) has been presented as both a diplomatic success and a victory for common sense, representing considerable progress in overcoming the deadlock the United Nation (UN) negotiation process had been in since the Copenhagen COP15. Its ambition is indeed great ${ }^{1}$ and unprecedented. ${ }^{2}$ However, upon closer examination of the contents of the agreement-lack of binding commitments, late revision of 'Intended Nationally Determined Contributions' (INDCs), ${ }^{3}$ absence of a roadmap to reach greenhouse gas (GHG) emissions reductions, non-inclusion of air and sea transportation sectors - the COP21 epitomizes old, and perhaps even growing difficulties that negotiators meet when discussing an urgently needed global, strong, and binding compromise. Climate policy appears as an expanding universe of regional exceptions and fragmentation as most countries try to craft their own take on energy transition (Rayner 2010), at times likely disregarding the fundamental principle of common but differentiated responsibilities.

One of the core solutions for such a transition, proposed by many economists but absent from the Paris Agreement, is the definition of an international price of carbon emission, which appears in practice extremely hard to achieve and insufficient to counter biodiversity loss or achieve broad environmental goals. It is, nevertheless, very much a precondition for international sustainable production and consumption, since price is the foremost economic signal to help orient economic players. It stimulates investments and innovation in cleaner production processes and provides a new source of financing for public policies, be they environmental or developmental.

As of this writing, the most important regional greenhouse gas pricing system is the European Union Emissions Trading Scheme (EU ETS). Spearhead of the European climate policy, this carbon market has since its inception been used as a model by other countries and regions. Many regional markets now exist in North America, most of them based on voluntary participation. Of note, China has also implemented seven regional markets since 2013 and is looking to merge them by 2017. In practice, however, the concrete results of the EU ETS are modest, since the market is only regulating 40 per cent of total European emissions. However, above all, tradable emission markets are ridden with many structural flaws, which result in a final pricing of the carbon ton that is much too low. Prices thus lose their incentive function and virtuous playersthose economic agents who have already started to invest in clean technologies - are found to be at a disadvantage. ${ }^{4}$

\footnotetext{
1 Illustrative of the ambition level of the Paris Agreement is the obligation for the highest GHG emitters to compensate damages suffered by the poorest and most vulnerable countries, and to contribute financially to mitigation and adaptation by the latter, according to articles 8 and 9 .

${ }^{2}$ For instance, article 2.1 (a) of the Paris Agreement includes, as a means to strengthen the global response to climate change: [h]olding the increase in the global average temperature to well below $2{ }^{\circ} \mathrm{C}$ above pre-industrial levels and to pursue efforts to limit the temperature increase to $1.5^{\circ} \mathrm{C}$ above pre-industrial levels, recognizing that this would significantly reduce the risks and impacts of climate change' (Paris Agreement, article 2.1 (a)).

${ }^{3}$ Through INDCs, countries determine their contributions in the context of national priorities, circumstances, and capabilities. It is noteworthy that INDCs are based on a 'bottom-up' approach, as opposed to traditional United Nations Framework Convention on Climate Change (UNFCCC) negotiations.

4 Recent reform proposal suggestions submitted by the European Council (EC) are leaning towards a higher, incentive, price. However, these proposals will affect the main advantages of the carbon market, namely countercyclicity and decentralization (in other words, carbon pricing by public authorities and no longer by market operators).
} 
Among the many identifiable reasons accounting for international inertia in the field, it appears that the weakness of prices (i.e. taxes and carbon market prices) might be related to a reasonable fear of competitiveness loss, notably in heavy industries (Branger et al. 2013). Indeed, one of the predominant political arguments for such low prices to internalize environmental externalities is the (real or conjectured) loss of competitiveness for local businesses in a globalized economy. According to this argument, local enterprises are confronted with international competitors that would indeed be either exempt of environmental charges, or, if they exist, under less constraining regulations than those existing in developed countries. Businesses respectful of environmental regulations are therefore forced to accept international competitiveness loss or offshore their production to countries with less constraining frameworks, thus annihilating efforts made in virtuous countries.

In order to avoid such perverse economic and environmental effects, several developed countries, such as France and the United States (US), have been devising adjustment systems to guarantee the efficiency of their environmental policies. These mechanisms are called 'border carbon adjustments' (BCAs). A BCA is a tariff measure that internalizes carbon emissions into the price of a given imported product. It is, therefore, a fiscal instrument, which is used in complement of carbon emissions reduction tools, such as a carbon market or a carbon tax, and targets internationally traded goods. A BCA can receive many forms and several instruments have been proposed in draft laws or policy analyses. For instance, a BCA may consist in quota restitutions for importers or a border carbon tax. Its primary objective is to level the playing field between domestic producers facing costly climate change measures and foreign producers facing very few.

France and Italy have repeatedly demonstrated their interest in such mechanisms at the European level: BCAs would be enforced in the most energy-intensive sectors (e.g. those that bear simultaneously the weight of environmental regulation and international competition), and would target selectively those countries that have not undertaken appropriate commitments, according to their capacity and responsibility in climate change, within the international environmental framework on climate change. ${ }^{5}$ In the same line of thought, economist Joseph Stiglitz has been campaigning for a European tax on GHG-rich American imports (Stiglitz 2006). Another example is the 2009 US Waxman-Markey bill, which sets both a BCA mechanism and a tradable emissions permit market, ${ }^{6}$ a solution that the US had already implemented in the past. $^{7}$ Other developed countries, such as Japan and Australia, are studying diverse solutions, and will inevitably be influenced by their European and American counterparts. In Europe, however, strong opposition to such initiatives persists, most notably in the United Kingdom. The same obviously applies to developing countries, although some voices have been raised in favour of

\footnotetext{
5 Programming bill $n^{\circ}$ 2009-967 of 3 August 2009 for the implementation of the Grenelle de l'Environnement stated in article 2 that 'France will support the implementation of a border adjustment mechanism on imports from countries that refuse to contribute according to their respective responsibilities and abilities to the global effort in GHG emissions reduction after 2012' (translation by the authors) (France 2009: article 2).

${ }^{6}$ A tradable GHG emissions permits market could have been created in 2012 at the federal level in the US, but this legislation, passed by the House of Representatives in 2009, was rejected by the Senate. Such market was aimed at reducing emissions by 17 per cent in 2020 compared to 2005 levels (and not 1990 levels) (Schott and Fickling 2010).

7 The US have, on two different occasions, applied border tariff adjustments (BTA). These adjustments did not apply to carbon emissions but were related to environmental nuisances. In 1986, a BTA was imposed on chemical imports. In 1990, as part of the Montréal Protocol, whose article 4 included the obligation for parties to impose import and export bans on controlled substances of non-parties - and despite this obligation becoming moot, because ratification was already nearly universal — the US implemented a BTA on CFC gases to limit the degradation of the ozone layer (Ireland 2010).
} 
BCAs (Mattoo and Subramanian 2013) amidst a growing recognition of the need for a satisfying global framework. ${ }^{8}$

It is noteworthy that, even in the scientific literature, BCAs are still controversial. The foremost argument against their enforcement, as expected, argues that such unilateral measures are mere kludges. According to Markusen (1975), the universal enforcement of a carbon price would be more relevant and efficient. Houser et al. (2008), as well as Dröge et al. (2009), further argue that it could slow down international cooperation on climate change, trigger economic retaliation, and foster a return to protectionism, or stimulate emission reduction costs transfers through trade effects. However, it is also arguable that, considering the weakly binding and limited country-level mitigation provisions reached in the negotiations under the United Nations Framework Convention on Climate Change (UNFCCC), unilateral action is more useful than the status quo (OECD 2014). It is also defendable that carbon leakage might diminish the environmental international engagement of most parties. ${ }^{9}$

Based on the discrepancy between the urgency of climate issues and the meagre results achieved in international negotiations, as the recent COP21, the purpose of this paper is to weigh the usefulness of $\mathrm{BCAs}$ as a complement to strong regional or domestic environmental regulation. This will lead us to the fundamental question of the interplay of economic competitiveness and climate change, which will be studied in Section 2, before the economic challenges posed by BCAs in order to reach fairness in its design and implementation is analysed in Section 3. In Section 4, we will shed light upon the legality of BCA mechanisms according to International Trade Law, while Section 5 will seek to contextualize the implementation of BCAs and provide an assessment of policy-related implications. We will outline, in particular, how BCAs could be used as an engine of a necessary economic transition, for developed and developing countries equally. Finally, Section 6 provides concluding remarks.

\section{Competitiveness and carbon leakage}

Environmental policy instruments fall into two categories: they are either of a regulatory (e.g. quotas, standards, certifications) or economic (e.g. taxes, tradable emission permits-TEPs ${ }^{10}$ ) nature. In both cases, they intend to internalize environmental externalities. ${ }^{11}$ As introduced earlier, BCAs can be perceived as commercial measures devised to level the playing field between domestic and foreign players whose position before environmental regulation is asymmetrical. Their virtuous effect on competitiveness, ${ }^{12}$ and even in increasing global efficiency (Böhringer et al. 2012), is well documented in the growing economical literature. ${ }^{13}$

\footnotetext{
${ }^{8}$ In 2010, India declared its intention to bring BCA measures before the World Trade Organization (WTO) Dispute Settlement Body, but has since softened its stance, based on the idea that developed countries cannot simultaneously commit to a significant reduction of their emissions and bear the weight of a large reduction of their economic activity (OECD 2014).

${ }^{9}$ Free permit allocation is important in the EU ETS system even though they have been gradually reduced. This kind of allocation, which can be likened to a disguised subsidy, stems from the fear of carbon leakage.

10 TEPs can also be referred to as 'tradable emission quotas' or 'carbon markets'.

${ }^{11}$ Externalities are external effects created by an economic agent's activity trading a free advantage, or a damage (climate degradation for instance), without monetary compensation.

12 See, in particular, Demailly and Quirion (2008: 497-504). Other economists defend a contrary position, as Weber and Peters (2009: 432-40).

${ }^{13}$ See OECD (2014) for a complete survey of the literature on the topic.
} 
For instance, if European producers, notably those from energy-intensive sectors, compensate rising costs linked to the implementation of the EU ETS on the final customer, they might lose domestic market shares to foreign competitors, which, in turn, would reduce their ability to sell. Conversely, if they do not apply such compensation, their sales will not be affected in the short run, but their profits, and over time, their investments will shrink, which will reduce their ability to win. In the end, it may lead to a transfer of investments from European companies to foreign markets, as well as a joint loss of market shares on domestic and foreign markets, resulting in severe job loss and a rise of GHG emissions outside Europe-in other words, in carbon leakage.

Such carbon leakage can be further strengthened through energy price channels. Climate policies have indeed a negative effect regarding international fossil energy prices (Blanchard et al. 2006) - the use of fossil energy is facilitated in countries that do not internalize environmental externalities. All sectors are concerned and no BCA mechanism is able to prevent fossil energy prices from decreasing on international markets. Therefore, in addition to carbon leakage, which is a direct effect, the indirect and more general consequences on the domestic economy of a given country also require consideration.

According to the European Commission (EC), out of 258 sectors and activities, 164 are exposed to a 'significant risk of carbon leakage. ${ }^{14}$ These leakages represent one-quarter of EU ETS regulated emissions. The most exposed sectors are naturally those with the highest level of GHG, oftentimes also the most energy-intensive. At the European level, the most affected sectors by EU's environmental regulation are cement, aluminium, steel, and power industries. ${ }^{15}$

Finally, it is worth highlighting that two main components of carbon leakage can be distinguished:

- An 'operational leakage', i.e. the operational delocalization of a domestic business, induced by environmental constraints, to less regulated foreign markets;

- An 'investment leakage', i.e. the redirection of investment flows from environmentally regulated domestic markets to foreign countries where such regulatory framework is absent. The impact of this form of leakage is long term and can be more important than the former in highly capital-intensive industrial sectors.

\section{BCA implementation}

The implementation of a BCA requires a clear definition of its field of application, in terms of product scope, instruments, and countries. The definition of a border adjustment instrument will thus entail to answer the following questions.

\footnotetext{
14 The Commission's criteria to identify sectors with 'a significant risk of carbon leakage' are: (i) a trade intensity index superior to 30 per cent; (ii) a carbon cost exceeding 30 per cent of its gross added value; or (iii) a trade intensity superior to 10 per cent and a carbon cost exceeding 5 per cent of its gross added value. According to the Commission's survey, 117 sectors presently meet criterion (i), 2 meet criterion (ii), and 27 meet criterion (iii) (Monjon and Quirion 2010).

15 Notwithstanding the fact that the power sector cannot be delocalized, owing to the complexity of its transportation, it plays a crucial role in the economy as an input for all sectors.
} 


\subsection{Which regulating instrument(s)?}

Most climate policies seek to use a combination of various instruments, but market signals have often been a major segment of such measures. ${ }^{16}$ Indeed, when dealing with environmental issues and in debates regarding the implementation of a $\mathrm{BCA}$, economic instruments have largely been favoured instead of regulatory instruments. They aim to encourage, through price signals, the voluntary (as opposed to compulsory) modification of behaviours to reduce pollution. Naturally, because they are both monetary signals, the use of economic instruments highly enable the implementation of BCAs. BCAs will thus complement preexisting domestic economic tools established by national environmental regulation.

In general, BCAs may consist in (i) a tax on imported products based on taxes applied on similar domestic products (tax adjustment on imports); (ii) tax credits on exported products (tax adjustment on exports); (iii) mandatory acquisition of emission permits in sectors where carbon leaks have been identified; or (iv) the allocation of free permits for those sectors subject to high competition. Each of these mechanisms can be implemented according to varied terms and conditions. The definition of a BCA depends as well on preexisting instruments in the regulated zone.

A border carbon tax may supplement a carbon tax on polluting activities of a given country or zone, or complement a carbon market. Tradable permits cannot be added to a carbon tax because they require an operating carbon market-they would take the form of purchased, allocated, or restituted permits instead (see Figure 1).

${ }^{16}$ It should be noted that there is a measure of scepticism concerning the efficiency of carbon markets, particularly in Australia and in the US. In addition, economic instruments may be inefficient for certain types of pollutants or of environmental nuisances. For an analysis of environmental taxes and carbon markets, see Bueb (2014). 
Figure 1: Advantages and drawbacks of BCAs

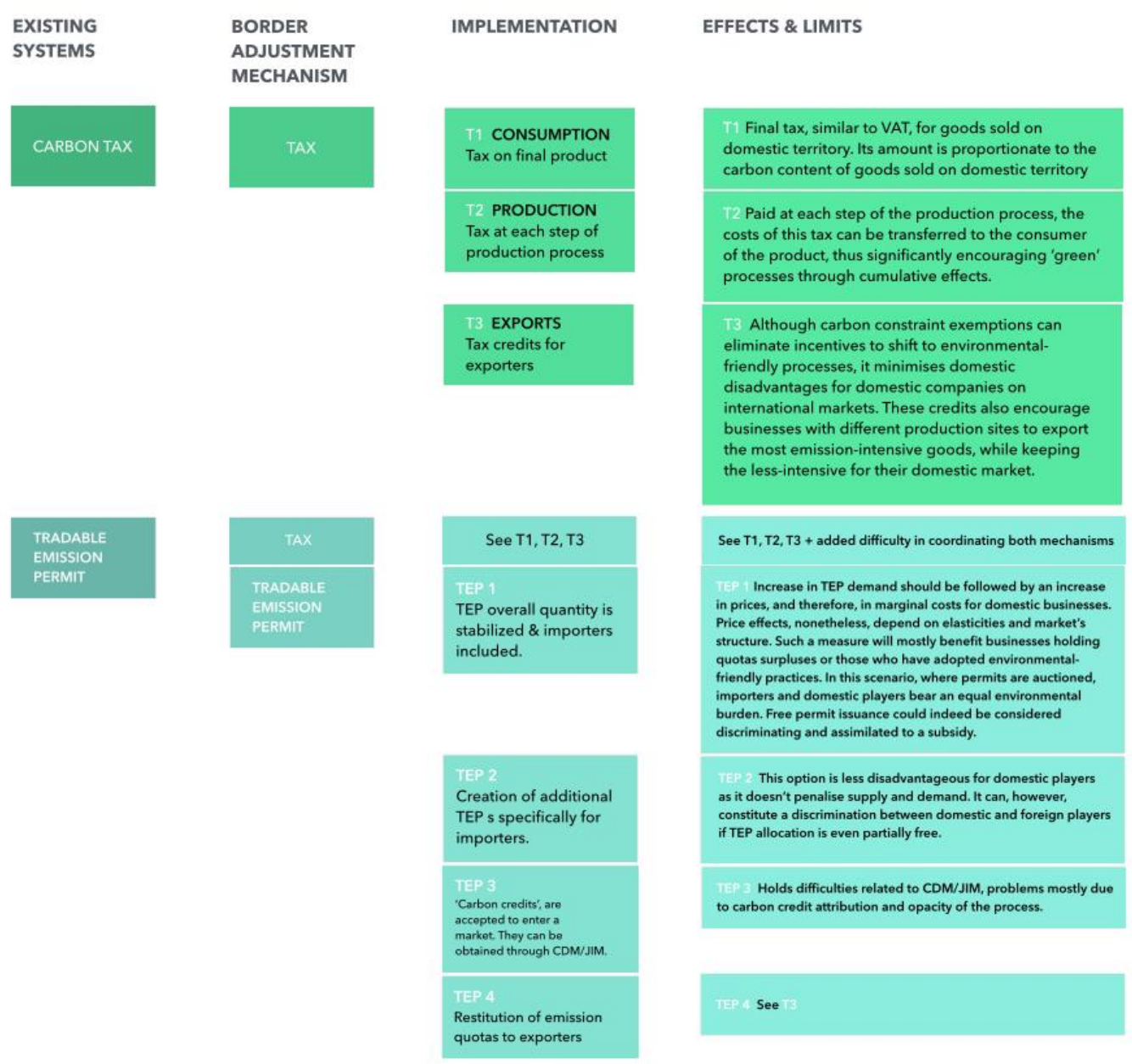

Notes: CDM: Clean Development Mechanism; JIM: Joint implementation Mechanism.

Source: Authors' compilation based on research.

\subsection{How to evaluate the carbon content of imported products?}

It is important to evaluate correctly the carbon content of products in order to implement fair BCA measures. In theory, all importers (i.e. firms located outside an environmentally regulated area with a BCA who sell in the zone) should be subjected to emissions reduction obligations to prevent an environmental dumping effect from which some companies might benefit. Depending on the country, however, environmental constraints differ, and the application of distinct BCAs according to each target country is not an easy task since a lot of information is needed to correctly evaluate and categorize environmental regulations in each of them. Prices (i.e. tax value or the purchase price of a permit bought by importers) will nonetheless need to be uniform - they will be, for instance, based on average values.

Yet, such a uniform price may suppress individual countries' and individual companies' initiatives regarding emissions reduction, since virtuous players remain comparatively unrewarded for their efforts. As an example, we may consider two importers of the same product. Firm A has invested in green production technology. This firm emits less GHG but is subject to additional costs, precisely due to its investment. Firm B uses a less costly, high GHG technology. Consequently, firm B's product is less expensive than firm A's. If the BCA is uniform (i.e. the same for all similar products), A will be penalized compared to B since the choice to pollute less 
at a higher cost will not be compensated by a lower BCA. There is therefore no incentive to invest in clean technology. A differentiated BCA system would reward efforts in emissions reduction, but in practice still appears unmanageable to put into place perfectly.

To lessen the problem, since it seems impossible to eliminate it, a first solution could be to encourage importing companies who would willingly pass an audit on the carbon content of their products. Another possible option would be demanding that companies give verifiable evidence of environmental regulation compliance, thus providing carbon content information, for instance through a certifying body. Such a disposition might, however, prove difficult to require from small importers considering the high administrative costs involved. In addition, such a demand might be considered discriminating, since not all companies would be subjected to this requirement.

Two other approaches, applied in conjunction or independently, are proposed in the literature: 'top-down' methods, using input-output analysis to estimate embodied energy, CO2 emissions, pollutants, and land appropriation of international trade activities, and 'bottom-up' approaches, based on the calculation of embodied carbon through the examination of production processes of specific products. The former seems too broad and, therefore, not easy to apply. The latter, more realistic, involves two methods: the 'best available technology' (BAT) and the 'predominant method of production' (PMP). According to the PMP method, the country of import would apply a border adjustment by assessing the carbon embedded in an import in relation to its own domestic production processes (Zhang 2010: 19). As for the BAT method, the country of import would apply a border adjustment by assessing the carbon embedded in an import compared to what the carbon emissions would be if the best available technology had been used (Ireland 2010).

The BAT appears to be the best method to the authors. It serves as a reference to assess the carbon content of imported goods, making carbon content evaluation by an independent organism easier through the application of a single procedure used as an international standard. Furthermore, such a measure would elude the issue of cleaner goods produced in foreign countries than those manufactured in the regulated zone. ${ }^{17}$ Offering an impartial criterion, the BAT could possibly obtain international approval and allow for the definition of international standards of production. Such approach to evaluate the carbon content of products leads, however, to a comparative assessment of production methods and processes, which might also be very difficult to put into practice. In fact, in a highly competitive environment where technology is a strategic advantage, producers are rarely willing to disclose information on their production techniques, nor on the most efficient technology in their sector. Furthermore, once defined, BATs would still be facing the situation of imported products cleaner than the adopted standards. An over-allocation of TEPs or a subsidization of these products could thus be complementarily considered in order to ensure positive discriminatory treatment to those products and avoid discouraging progressive investment in cleaner technologies.

\footnotetext{
${ }^{17}$ When discussing BCAs, it is often assumed that the goods produced in a regulated zone will necessarily be lower in carbon content than those produced outside of that zone will. Yet, this cannot always be verified. It is therefore necessary to address this question upon implementing a BCA: a subsidy for the importer could be a possibility, as well as an exemption from the BCA in question, or the use of a production process as a standard for environmental regulation in the zone.
} 


\subsection{Which sectors or products to target?}

Whatever form a BCA might take, it bears on processes and not products. As an instrument, it is thus blind to the product itself. The global political sensitivity of BCA enforcement renders precise definition of sectors and products all the more critical. ${ }^{18}$

Carbon content is nevertheless highly variable throughout the production process, depending on products, and across sectors. As a result, two similar products from the same sector, produced by similar companies, can have starkly different emission rates. Within a single sector, similar goods can also be produced with very different methods. A bottle of mineral water, for instance, will be more or less energy-intensive depending on the plant where it is produced and/or its home country (quantity). Furthermore, even if the final energy used is the same, the primary source of energy (gas or coal) will make a difference in the carbon content (quality). Bearing in mind that BAT references do not take indirect emissions into account (for instance, emissions due to transportation) and also because of the difficulties firms have in evaluating their energy mix, the relevance of the BAT method for audits may be challenged (see Box 1). This explains why the International Energy Agency (IEA) has created a specific emission ratio by MWh, which tracks average GHG emissions per country for each megawatt produced. It would likely be possible to evaluate indirect emissions with better accuracy if similar emission ratios were included in the total sum of emissions per product.

\section{Box 1: The nexus of carbon content}

In most current studies, carbon content refers to the sole production process while it could take into account the entire carbon production chain as well as indirect emissions. BCAs on the total carbon content and/or added carbon could be more accurate. By establishing the BCA base on the amount of carbon emitted for both production and transportation of products, it would be possible to take into account the entire emissions involved in the production of goods and particularly the non-energy related emissions, even though these emissions are often low. This type of mechanism would have the decisive advantage of providing accurate knowledge on GHG emissions, thus broadening the scope of taxable GHGs, while preventing any distortion of competition. It requires, nevertheless, the standardized and reliable measurement of GHG emissions at each step of the production and distribution processes of the taxable product, which entails high administrative costs. This would further be complicated for imported products, requiring either to rely on hardly verifiable information provided by importers, or using standard values, thus increasing the risk of an international dispute. In addition, given the fragmentation of the production chain, products using components produced in an environmentally regulated zone subject to BCAs could thus bear a double regulation. In order to avoid overmeasurement of emissions, the amount of carbon of the specific components under regulation should be subtracted from the total carbon content.

\subsection{Which countries would be affected by this mechanism?}

At the present date and due to the existing differences in climate change regulation between developed and developing or emerging economies, BCAs would likely primarily affect the socalled BRICS (Brazil, Russia, India, China, and South Africa) and other developing countries. ${ }^{19}$

Least developed countries (LDCs) could nevertheless be exempted, in order to protect their fragile development-recent discussions in this direction have taken place in the US. However,

\footnotetext{
${ }^{18}$ France has suggested implementing BCAs by sector, not by products.

${ }^{19}$ If developing countries were to refuse to implement such measures along with developed countries, the BRICS would likely be the first countries targeted by BCAs. It should be underlined that middle-income countries, which are not LDCs or BRICS, could be also affected by a BCA.
} 
exceptions of this kind are probably not the best course of action because LDCs would thus run the risk of being altogether excluded from the decision-making process. ${ }^{20}$ Besides, risks of trade infringement through LDCs are real in globalized and fragmented production processes, where it is difficult to track products and component parts, and this would considerably weaken such a BCA mechanism.

\subsection{Which flows?}

In order to address climate change effectively, most sectors should in theory be subjected to environmental policies. Whether a given imported product is liable in whole or in part to a BCA will, however, naturally depend on the instrument in use (tax or TEP). Carbon markets cannot deal with all emissions, in particular small firms' emissions, given the need to standardize TEP (1 TEP $=1$ tonne of carbon dioxide equivalent). As noted earlier, the European carbon market, for instance, only bears on 40 per cent of domestic emissions. In this case, taxing by tonne of emitted carbon equivalent would seem more appropriate, because it would cover the whole of produced products.

Another question is raised regarding exports outside an environmentally regulated area. A BCA can restore a fair level of competition within a regulated area. Protecting European businesses, for instance, could involve a total exemption on their exports. Such a measure, however, would most likely encourage big emitter plants to produce for export markets, while lesser emitter plants would concentrate on the European market. A more relevant option might be to base the adjustment level for exports on a uniform benchmark, such as a BAT, even if it might then be considered a subsidy for exporters and need to abide by International Trade Law provisions.

As this section of the study demonstrates, BCA implementation encounters numerous practical and economic difficulties, carbon cost evaluation being particularly challenging. ${ }^{21}$ However, these challenges, far from hampering BCA implementation, can steer the design of such measure towards the most efficient and fairest emission reduction mechanism, on the way to clean energy transition. Due to its effects on international competition and the international market, a BCA would, of course, also need to be compatible with countries' obligations in respect to International Trade Law. In the context of GHG limitation, a BCA design and implementation should also take into account the principle of common but differentiated responsibilities enshrined in International Law.

\footnotetext{
20 Such difficulty for LDCs was clearly observed during the Copenhagen's negotiations, where dealings were considered to be facilitated by discussions held between the main polluting countries only.

${ }^{21}$ To avoid these manageable challenges, France has devised the path to determine the level of a BCA using the global GHG emissions volume per capita or per unit of gross domestic product (GDP), rather than the amount of carbon contained in a product (OECD 2014).
} 
A BCA adopted by a member of the World Trade Organization (WTO) should comply with the obligations undertaken by such member within the organization. The following sub-Sections briefly present insights on the ways the General Agreement on Tariffs and Trade (GATT) ${ }^{22}$ allows contesting ${ }^{23}$ or legitimizing BCA mechanisms.

\subsection{Challenging a BCA under the GATT principle of non-discrimination}

A core obligation established among WTO members is the non-discrimination principle. This principle is notably reflected in the 'national treatment' and the 'most favoured nation treatment' obligations. With respect to trade in goods, which is governed by the GATT, such obligations may be summarized as follows:

- National treatment (article III of the GAT'T) prohibits discriminatory treatment through internal taxes or other internal charges (article III: 2) between national products and foreign products that are considered like products or directly competitive or substitutable products. It also prevents a WTO member from applying a discriminatory treatment between like national and foreign products through laws, regulations, and requirements (article III: 4) (GATTT 1947: article III; see, for instance, Richieri Hanania 2009: 86-7);

- The Most Favoured Nation treatment (article I of the GATT) requires that a preference accorded to a product originating in or being exported to a WTO member be extended to similar products originating in or destined for the territories of all other members (GATT 1947: article I; see, for instance, Richieri Hanania 2009: 86).

Besides the non-discrimination principle, and in order to ensure market opening and transparency, tariff restrictions are preferred to quantitative restrictions (e.g., quotas, import or export licenses). Indeed, according to article XI of the GATT and subject to the exclusions foreseen in that provision, WTO members are not allowed to adopt quantitative restrictions to trade and quantitative restrictions must be administered in a non-discriminatory manner (article III of the GATT). Members must also notify to the WTO quantitative restrictions in force. BCAs might be associated to a quantitative restriction if a member decided to impose,

\footnotetext{
${ }^{22}$ For clarification purposes, questions regarding climate change within the WTO go beyond the GATT framework, also reaching other WTO agreements. Moreover, a country wishing to implement a BCA in its territory will need to comply with obligations it has also undertaken under other international treaties, including bilateral and regional trade agreements.

${ }^{23}$ As recalled by the OECD, 'measures that attempt to correct for carbon leakage, such as BCAs, are likely to be challenged by WTO members with export-oriented economies and relatively lax carbon regulation' (OECD 2014: 15). A brief description of the WTO dispute settlement system offered by the OECD may be worth quoting here:

a [WTO] member may contest another member's domestic measures as a violation of WTO law by bringing a challenge to the Dispute Settlement Body (DSB). Following consultations, and at the request of the complaining member, the DSB establishes a panel of experts to adjudicate the merits of the case. If a panel were to find that a BCA measure was indeed a violation of WTO law and this finding was not successfully appealed to the Appellate Body, the country in violation would have to bring the measure into conformity with its WTO obligations, for example, by changing its legislation. If the losing party does not bring the measure into conformity within a reasonable period of time, then the challenger may seek compensation, often in the form of tariff reductions or the lifting of import quotas. If the two parties are unable to reach an agreement on the appropriate level of compensation, the winning party may seek authorization from the DSB to suspend trade concessions or other WTO obligations against the member in violation pending removal of the WTO inconsistent domestic measure or the agreement of a mutually satisfactory solution between the parties (OECD 2014: 15).
} 
exclusively on importers, the obligation to buy quotas on the carbon market, for example. It is, however, likely that a member would rather in such a case establish a regulatory scheme applicable to its entire market, including domestic producers, which would be examinable under article III mentioned above (OECD 2014: 19).

In case a BCA adopted by a W'TO member is considered by another member as altering the terms of competition existing in the international market by granting benefits exclusively to domestic producers, to the disadvantage of foreign producers, such BCA mechanism might be contested before the WTO Dispute Settlement Body (DSB) for alleged violation of the national treatment obligation under the GATT. The WTO judge will firstly need to assess whether the products at issue are 'like products' or 'directly competitive or substitutable products' according to article III of the GATT. The 'likeness' of products is evaluated on a case-by-case basis in WTO law, according to the following criteria taken from the GATT 1947 case law: 'the product's end-uses in a given market; consumers' tastes and habits, which change from country to country; the product's properties, nature and quality' (WTO 1996a: 20). Based on those criteria, carbon-intensity may be raised as a distinctive feature between a domestic and a foreign product if a member demonstrates, for instance, that consumers have a preference for products with a lower carbon print, even if the products are physically identical. ${ }^{24}$

It is also tenable that, as long as the BCA entails the same level of constraint on importers and domestic producers, a BCA would not be discriminatory under the GATT national treatment obligation and would comply with WTO law in this regard. For instance, the GATT allows WTO members to apply a tax adjustment at the border when it authorizes members to levy, at the importation of a product, a charge equivalent to an internal tax, which directly or indirectly affects national like products (article II: 2 (a) of the GAT'T). The same rationale applies to tax adjustments at exportation when these adjustments simply correspond to the exemption or refund of internal duties or taxes applied to like products destined for consumption in the country of origin or exportation. Those adjustments are therefore not subject to the WTO provisions regarding anti-dumping or countervailing measures (article VI: 4 of the GATT). In practice, and depending on the type of BCA chosen by a member, such equivalency of treatment between domestic and foreign products can however be difficult to demonstrate. For example, a tax imposed on importers of goods while national producers of like products are subject to a carbon market or a market of emission permits (and not a tax) would probably be more difficult to justify or to prove equivalency of.

In the event a BCA adopted by a WTO member was contested by another member before the WTO judge based on the GATT national treatment obligation, the difficulties mentioned in Sections 2 and 3 of this paper would also undoubtedly complicate the parties' arguments and the assessment to be made by the WTO judge (e.g. WTO-UNEP 2009: 101-3). In fact, in order to evaluate the impact of a specific BCA on competitive foreign products, it would for instance be necessary to measure precisely the carbon content of a product and the foreign product it is compared to, as well as to justify the determination of sectors and imported products, which are targeted by that BCA. On the other hand, it is also defensible that those difficulties might become less significant with the progressive development and larger acceptance of norms and objective BAT references for the calculation of carbon prints.

${ }^{24}$ This might be a difficult task in practice, though. See OECD (2014: 16), which recalls that 'some authors argue that market studies most often will show that consumers generally ignore the processes and production methods (PPMs) of products.' 
Based on the most favoured nation treatment obligation and its prohibition of discrimination among WTO members, violation of the GATT might in addition be alleged with respect to differences in BCAs applied according to the (foreign) targeted country of origin or destination of a product. One of the exceptions to the most favoured nation treatment in the WTO is the special and differential treatment in favour of developing and least-developing countries, enshrined in varied provisions of the WTO Agreements. ${ }^{25}$ Its implementation is, nevertheless, dependent on certain conditions. In fact, according to the special and differential treatment in the WTO, a member wishing to favour LDCs when defining its BCA mechanism-as proposed earlier in this paper-would need to employ well-defined and reasonable criteria, which would furthermore need to be applied in a non-discriminatory manner to every developing country presenting the same circumstances. ${ }^{26}$

Finally, the choice of countries targeted by a BCA could also possibly be challenged under the more general notion of 'shared but differentiated responsibilities', recognized nowadays as a component of sustainable development. ${ }^{27}$ In fact, the principle of shared but differentiated responsibilities has been consecrated in the UNFCCC and it is defendable that it has been integrated as well into WTO law through the concept of sustainable development, which is acknowledged as an objective of the organization. ${ }^{28}$ Such principle requires that different countries' capacities, social and economic situation, and historical contribution to climate change be taken into account. It would therefore not be unlikely for a WTO judge assessing the design and implementation of a BCA to consider those elements in their legal reasoning and admit that the BCA may apply dissimilar treatment to different foreign countries according to their specific circumstances and their historical contribution to climate change.

${ }^{25}$ For an overview of the special and differential treatment and recent discussions on this theme within the WTO, see WTO 2015.

${ }^{26}$ In the case European Communities-Conditions for the Granting of Tariff Preferences to Developing Countries (DS246), the Appellate Body highlighted that identical treatment is required to countries benefitting from the European Generalized System of Preferences having the same 'development, financial and trade needs' (WTO 2004: $\left.\int \$ 160-7\right)$. For a brief chronological overview of and comments on the special and differential treatment at the WTO, see Richieri Hanania (2009: 137-40).

27 The principle of shared but differentiated responsibilities has been enshrined in Principle 7 of the 1992 Rio Declaration on Environment and Development as follows:

In view of the different contributions to global environmental degradation, States have common but differentiated responsibilities. The developed countries acknowledge the responsibility that they bear in the international pursuit of sustainable development in view of the pressures their societies place on the global environment and of the technologies and financial resources they command. (United Nations 1992: Principle 7)

${ }^{28}$ In the Preamble of the Marrakesh Agreement Establishing the World Trade Organization, WTO members have recognized

that their relations in the field of trade and economic endeavour should be conducted with a view to raising standards of living, ensuring full employment and a large and steadily growing volume of real income and effective demand, and expanding the production of and trade in goods and services, while allowing for the optimal use of the world's resources in accordance with the objective of sustainable development, seeking both to protect and preserve the environment and to enhance the means for doing so in a manner consistent with their respective needs and concerns at different levels of economic development (WTO 1994: Preamble, emphasis added).

See Morosini (2010: 717-25), defending that border adjustment measures established by the US Climate Bill proposed by Senators Waxman and Markey are inconsistent with WTO law, inter alia because they do not respect the principle of shared but differentiated responsibilities. 


\subsection{Resorting to the GATT general exceptions regarding health and environment protection}

In the advent of a contested BCA brought before a WTO judge and considered discriminatory by the latter, and therefore in violation of the GATT, the member having adopted the BCA would likely attempt to justify it on the grounds of the general exceptions under article XX of the GATT. These general exceptions are part of the general balance of rights negotiated by WTO members (EC-Hormones (DS26 and DS48) and US-Shrimp (DS58)) (WTO 1998a, 1998b) and aim, among others, to allow members to adopt measures for health and environmental protection that might otherwise be considered contrary to GATT obligations. Article XX (b) and (g) of the GATT reads as follows:

Subject to the requirement that such measures are not applied in a manner which would constitute a means of arbitrary or unjustifiable discrimination between countries where the same conditions prevail, or a disguised restriction on international trade, nothing in this Agreement shall be construed to prevent the adoption or enforcement by any contracting party of measures: (...)

(b) necessary to protect human, animal or plant life or health; (...)

(g) relating to the conservation of exhaustible natural resources if such measures are made effective in conjunction with restrictions on domestic production or consumption; $(. .$.

Article XX (b) requires the fulfilment of a necessity criterion. According to W'TO case law, a necessity test implies a proportionality control of a measure with respect to the objective that a member is pursuing, as well as the assessment of the availability of alternative reasonable measures that might be less restrictive to trade but as effective. Such interpretation has been applied in the well-known cases, Korea-Beef (DS161 and DS169), EC-Asbestos (DS135), USGambling (DS285), and Brazil-Retreaded Tyres (DS332). ${ }^{29}$ In those cases, the WTO judge explained that a measure may be considered necessary based on the importance of the interest or value it protects, its contribution to the materializing of the objective pursued (effectiveness of the measure), and its degree of restriction to trade (WTO 2000: $\int \$ 160$ ). Once these conditions are all met, article XX (b) may be considered applicable by a WTO judge. When defending the non-applicability of article XX (b) to a BCA, a WTO member would thus need to demonstrate that other alternatives, as effective and less trade restrictive options existed.

Regarding article XX (g), the expression 'relating to' has been interpreted as meaning 'primarily aimed at' (US-Gasoline (DS2)) (WTO 1996b: 15-19), which is larger than the notion of 'necessary'. If a BCA is demonstrated to be primarily aimed at environmental objectives (and not only aimed at competiveness issues), article XX (g) might be considered applicable by the WTO judge. Moreover, in the case US_Shrimp (DS58), the WTO Appellate Body considered that the notion of 'exhaustible natural resources' should be read according to contemporary concerns regarding the protection and the conservation of the environment, as defined in recent

${ }^{29}$ See, on the evolution of the 'necessity test' in WTO law, Ruiz Fabri (2007: 189-221). 
international treaties. ${ }^{30}$ Such decision allows for an evolutionary interpretation of general exceptions in the GATT and demonstrates the WTO judge's wish to take into account environmental objectives as they are progressively established in International Law under the concept of sustainable development. Environmental concerns reflected in a BCA might therefore be positively considered by the WTO DSB based on contemporary environmentrelated concerns and recent climate change discussions.

However, the exceptions listed in article XX are also to be interpreted together with its introductory statement, the chapeau of article XX: a measure must not be applied in a manner which would constitute a means of arbitrary or unjustifiable discrimination between countries where the same conditions prevail, or a disguised restriction on international trade' (GATT 1947: article XX). In fact, should the challenged WTO member succeed in demonstrating that its BCA mechanism conforms to one of the exceptions of article XX mentioned above, the chapean of that same article, would still require the W'TO judge to verify how the contested measure has been applied. In a few words, according to the chapeau of article XX and its case law, the WTO judge will need to examine, cumulatively, if:

- The defendant has attempted to cooperate with other members in a non-discriminatory manner in order to diminish the restrictive effects that the contested measure may have on trade;

- The measure is sufficiently flexible to account for different conditions existing among countries, even if it is not required from a WTO member to expressly anticipate individual conditions of each member; and

- The conception, the base principles, and the structure of the measure do not testify to protectionist purposes. The environmental objectives of a BCA will need to be particularly highlighted in order for a member to respond to this condition.

WTO case law has shown that the conditions of the chapean of article XX remain the most difficult step to overcome when a member resorts to the general exceptions under the GATT. While the GATT principles exposed in this section may guide the design of a BCA, its consistency with WTO rules may only be considered on a case-by-case basis. In case of a dispute on the matter, the WTO judge will necessarily examine the economic features and obstacles identified in the preceding sections of this paper for each type of BCA, in order to assess their conformity to International Trade Law. Since their effects on international competition and their complexity may be significant, it is likely that, while certain BCAs might be considered as responding to the conditions required under one of the paragraphs of article XX, their acceptability according to the chapeau of that same article might be problematic. Any attempt to elaborate a BCA that respects WTO Law should therefore take into account the three cumulative criteria listed above.

Based on the economic and legal aspects put forward in the sections above, the following section discusses the acceptability of BCAs from a political sciences standpoint.

\footnotetext{
${ }^{30}$ See WTO (1998b): \129, which reads:
}

The words of Article XX(g), 'exhaustible natural resources', were actually crafted more than 50 years ago. They must be read by a treaty interpreter in the light of contemporary concerns of the community of nations about the protection and conservation of the environment. While Article XX was not modified in the Uruguay Round, the preamble attached to the WTO Agreement shows that the signatories to that Agreement were, in 1994, fully aware of the importance and legitimacy of environmental protection as a goal of national and international policy. 


\section{The political implementation of BCAs in the context of energy transition}

As highlighted earlier, the possibilities of conflict inherent to the implementation of border adjustment measures are significant: for some economists (Cosbey 2008), BCAs cannot function correctly. The existence of a carbon market would further complicate the implementation of such measure, mostly due to the difficulties in creating a level playing field (Bueb 2014). In contrast, other scientists (Monjon and Quirion 2010) see in this measure a way to act efficiently in favour of the environment, without waiting for a binding international climate agreement.

Indeed, the latest iteration of the UNFCCC negotiations in Paris at the end of 2015 still proves insufficient. Even though the COP21 has been a diplomatic success, the content of the Paris agreement remains shallow when considering States' commitments. The objectives stated in the agreement-i.e. capping at $1.5{ }^{\circ} \mathrm{C}$ to $2{ }^{\circ} \mathrm{C}$ the global temperature increase, as well as the reference to carbon neutrality - seem vague since no specific emissions reduction targets have been agreed upon by the Parties. The only measure, which can be viewed as constraining are the INDCs. Yet, to this day, the proposed contributions still lead towards an increase of at least $2.7^{\circ} \mathrm{C}$, due to strong assumptions on carbon capture and storage. Moreover, the scheduled revision of INDCs will not occur soon enough to respond to the urgency in limiting global warming and reducing carbon emissions accordingly (available corresponding 'carbon budget'). In addition, some INDCs have not been defined properly, setting long-term objectives without a roadmap to reach these goals. Furthermore, the COP21 agreement does not take into account the emissions coming from the maritime and air transportation sectors.

Consequently, the implementation of BCAs remains an effective tool for countries ready to implement, or having already committed to, a bold energy transition. BCAs can level the environmental commitment (INDC) among countries facing similar responsibilities in climate change. Moreover, a well-designed BCA should aim at answering the concerns of developed countries while promoting growth in developing countries, and should take into account other fundamental factors for energy transition. The sections below highlight two of those factors: the need to consider developing countries' interests and the complementary necessity of sobriety policies. ${ }^{31}$

\subsection{Energy transition, BCAs, and developing economies}

In recent years, as BCAs are gaining more interest from both governments and academia, the growing body of scientific literature has mainly focused on carbon leakage and competitiveness issues. However, in the heated debate on BCAs implementation, another obstacle is highlighted in the potential consequences of such measures on developing economies. Indeed, BCAs have also been interpreted as a commercial sanction towards developing countries and international negotiations related to this measure have proved to be complicated. This question has become a recurring argument against BCA implementation, but requires a more careful examination of the stakes for developing countries. An insightful analysis regarding this issue can be found in a study of climate change and trade policy (Mattoo and Subramanian 2013). Evaluating the different forms of BCAs and their consequences from both a trade and an environmental

\footnotetext{
${ }^{31}$ In the English-language literature, various terms are used to refer to the principle of primary energy consumption reduction by using less of an energy service: energy sparing, 'sustainable lifestyles and sustainable patterns of consumption and production' (COP21 Paris Agreement, Preamble), behavioural change, energy saving, energy soberness, energy sobriety, etc. The authors have chosen to use 'sobriety' in the present study, the translation of the French term 'sobriété', because it best describes our current energy overconsumption and its sort of 'hangover' results. Sobriety differs from efficiency (or efficient energy use), which refers to using less energy for a constant service.
} 
perspective, the authors of that study suggest what they deem the 'least undesirable' form of a BCA: '[a] border tax adjustment based on the carbon content in domestic production would broadly address the competitiveness concerns of producers in high-income countries while inflicting less damage on developing-country trade' (Mattoo and Subramanian 2013: 113). To ensure developing countries do not remain vulnerable to trade policy, international agreements on trade measures should be elaborated within the international climate change debate rather than future WTO negotiations.

Indeed, at the global level, matters turn out to be much more complex and intricate when considering the energy transition and economic development nexus. Finding new ways to frame the problem, and therefore to look for viable solutions without hampering development opportunities, has become both necessary and urgent. One such reframing can be found in Mattoo and Subramanian's proposal of a radical shift in the narrative of the problem as well as a transformation of the terms of international cooperation in mitigating climate change, highlighting the important role of technological transfer as a means of action. By challenging what they dub the 'narrative' problem, i.e. the historical perspective on the industrialized countries' responsibilities in climate change and the past 'colonization of emissions space', they contend that there should be a role reversal in leadership for climate change discussion, especially considering the fact that 'the stakes in the near to medium term are much greater for the DEEs, "dynamic emerging economies", than for today's rich countries' (Mattoo and Subramanian 2013: 1).

A decisive climate change issue for developing countries relates to technology generation and transfer. In fact, developing countries could rapidly meet emission reduction goals through accelerated technological change. Technology generation, diffusion, and management policies are a key component of climate change mitigation and adaptation at the global scale (IPCC 2014). The level of technological progress needed can only be achieved through international cooperation, by shifting from the sole financing of emission cuts to an investment in technology generation. For Mattoo and Subramanian (2013: 18), the formula of such cooperation could be ' $[\mathrm{t}] \mathrm{o}$ developing countries according to their growth needs; from developing countries commensurate with their economic dynamism, and to all the common good of planetary survival'. Although hopeful for the future, this formula will require very strong and arduous commitments to transform production and consumption practices as well as individual behaviours and perceptions, something short of a revolution.

However, reaching consensus on international technological cooperation might prove to be as difficult as achieving an agreement in international climate negotiations. Considering the urgency of climate change matters, the unilateral implementation of BCAs could represent more than a second best solution: in such a context, this type of mechanism appears to be, beyond a palliative solution, a necessity, considering the slow progress of significant international agreement on environmental matters. In fact, this type of measure could serve as an instrument to discourage environmental dumping and promote international involvement and significant mitigation commitments (beyond INDCs) in the framework of the 2015 Paris Agreement, as it could, for example in case of implementation by the EU, encourage EU partners to improve their environmental policies. Furthermore, resulting in an increase in prices in developed countries, BCAs limit consumption in the North and leave resources available for the South. As inequalities (of access to goods and of income) exacerbate environmental damage, which in turn further increases inequalities (UNDP 2011), BCAs could play an important role in promoting equity and development for developing countries. A BCA would, therefore, be one step among others towards energy transition and serious efforts in addressing climate change. 


\subsection{BCAs, an available tool to reshape the world}

Climate change issues, and environmental concerns at large, constitute a complex problem, which goes well beyond simple commercial and economic conditions. They relate to both the economy and the environment, but also to a social dimension. Often forgotten, if not obfuscated by its own complexity, this social dimension includes inequality and development issues related to burden sharing, ultimately translated into the principle of common but differentiated responsibilities towards a carbon-free world.

Green growth is often advocated, not as a means but as an end, in different forms (sustainable and inclusive growth or green economy) in order to address that objective. This type of growth entails the 'greening' of economic activities according to a particular logic that starts with renewable energy and ends with energy efficiency facilitated by technology. Yet this reasoning overlooks four essential elements. First, economic activity is parameterized by our ability to produce energy: the more energy per capita, the higher the growth potential in developed countries (Giraud and Kahraman 2014). Second, the ability to substitute the primary, high carbon energy consumed for renewable energy depends on the availability of materials needed for windmills or photovoltaic panels, as well as on the pace of deployment of these systems (Roman 2014). Actually, the historical energy return on investments (EROI) rates are decreasing, all energies considered, and as a consequence, more energy is needed to produce energy and to extract raw materials (such as rare earth elements, for instance), since the most accessible deposits have been or are becoming depleted. The scarcity of materials is not as much economic or geopolitical as it is energy-related. Furthermore, if renewable energy systems are deployed too fast, the newly created energy will be used for the production of other units of carbon-free energy production, rather than replacing current polluting energies (Pearce 2009). Third, the focus on renewable energy and energetic efficiency conceals the issue of energy embodied in products $^{32}$ or 'grey energy'. ${ }^{33}$ Fourth, the technological solution may prove hazardous. The benefits in energy efficiency achieved through technological progress are real, but remain insufficient to become a viable solution, particularly given the environmental urgency. The rebound effect ${ }^{34}$ is another issue for technological developments. Moreover, since innovation cycles continue to be variable and unpredictable, waiting for a major innovation that could completely change energy use seems too precarious.

For these reasons, green growth seems to be rather a myth. Sobriety policies are equally necessary as renewable energies and energetic efficiency towards energy transition. Often forgotten and disregarded because it entails a strong political will, this policy concept challenges certain aspects of economic growth. ${ }^{35}$ Sobriety policies aim indeed at classifying products according to utility and regulating their production and use. For instance, energy savings equivalent to the amount of energy needed for six households in Europe could be made if advertisement screens in train and subway stations were prohibited (Association NégaWatts 2011). Conversely, organic farming based on agroecological principles should be promoted, given the fact that such type of production of agricultural goods involves lower inputs and fewer cleanup operations. This is where sobriety collides with growth: any activity involving an over-

\footnotetext{
32 Embedded energy is the energy needed to produce a given good.

${ }^{33}$ Grey energy is the sum of embedded energy and all other forms of energy used throughout the lifecycle of a given good until its recycling.

${ }^{34}$ The rebound effect describes the process by which greater energy efficiency may lead to an increased energy use. 'Buy a more fuel-efficient car, drive more' is the most well-known rationale for the rebound effect.

35 The necessity of LDCs' growth goes without question, especially since fair reallocation of its output stimulates development.
} 
consumption of energy or even environment cleanup operations contributes positively to the gross domestic product (GDP).

The implementation of sobriety policies, followed by energy efficiency policies, and the deployment of renewable energies, ${ }^{36}$ reverses the traditional reasoning applied to climate policy and underlines the need for a strong, compelling regulation. Dealing with the complexity of the economical-environmental-social nexus, itself embedded in a fluctuating international context, national regulators must resort to various instruments to foster definite changes in behaviour. BCAs are an essential component of this array of instruments. They contribute to the development of more local, thus 'sober' activities.

In addition, limiting transportation has become a necessity, as the French ambassador in climate negotiations for the Paris COP21 previously underlined (Tubiana 1991). It should be noted that sea and air transportation are to this day still not subjected to emissions reduction (and are not included in the COP21 Agreement), despite the need for regulation of those sectors due to their specific transnational aspects. Transport reduction policies, perhaps supplemented by trade reduction policies, would encourage local production, circular economy, ${ }^{37}$ economy of functionality, ${ }^{38}$ and thus development, at any development stage. Again, BCAs may be seen, therefore, as regulatory instruments available for the national regulator to foster change in behaviour.

Moreover, the implementation of BCAs transcends the stakes of competitiveness and level playing field issues. Seeking to reach an equitable distribution of commitment, and considering the principle of common but differentiated responsibilities, it appears necessary to shift from national production-based emissions counts to a consumption-based approach. Taking into account the amount of GHG consumed rather than produced opens a fair route, between countries as well as within social categories, and encourages sobriety behaviours. In addition, BCAs become incentive schemes for developing countries to adapt production to local needs, which, obviously, is not the case for developed countries today. It also drives public authorities to take better care of their citizens' living conditions and to heighten education, health, and energy-access standards resulting in fairer allocation and reduced waste. Finally, this would motivate developed countries to rethink their environmental policy and to shoulder their responsibilities. BCAs would thus become an essential component of social and environmental justice. ${ }^{39}$ BCAs can help to depart from a business and macroeconomic logic.

In sum, minding carbon consumption would entail considerable commitments from developed countries if they want to meet their objectives of GHGs emissions reduction. Given the considerations and context exposed above, BCA enforcement would be, in all likeliness, necessary, together with paradigm shifts, which would breed strong incentives to ease developing countries' acceptance of this instrument. In the same vein, funds collected via BCAs should be

\footnotetext{
36 This point is of critical importance. Sobriety policies and energy efficiency would reduce primary energy consumption by 66 per cent. As a result, the need for renewable energies would be considerably reduced, paving the way to smoother raw materials sharing at the international level (Association NégaWatts 2011).

${ }^{37}$ The main goal of circular economy is to enable the production of goods and services while preventing excessive consumption and squandering of raw materials, and as to facilitate recycling.

38 A functional economy is one that optimizes the use (or function) of goods and services and thus the management of existing wealth (goods, knowledge, and nature). The economic objective of the functional economy is to create the highest possible use value for the longest possible time while consuming as few material resources and energy as possible.

${ }^{39}$ Poverty and environmental destruction are highly correlated (Laurent 2011; Keucheyan 2014).
} 
reallocated to objectives such as the production of more sustainable goods, innovation, technology, or skills transfer. The Green Climate Fund (GCF) could equally be made the recipient of all or parts of these funds.

\section{Conclusion}

The commitments agreed upon by the Parties during the COP21, and particularly the commitment to hold the increase in global temperature below $2{ }^{\circ} \mathrm{C}$ or $1.5{ }^{\circ} \mathrm{C}$, should lay the foundations for any energy transition strategy but also for economic transition policies. However difficult to meet, these commitments entail a profound, and voluntary, ${ }^{40}$ transformation of our societies. The BCA mechanism can enable our (over)consumption societies to move towards a sober, low-carbon society, which uses energy and resources thoughtfully. BCAs can act as a brake for the growth accelerator. BCAs turn out to be more than a simple restraint towards a given trade partner. It is, actually, a powerful means to share resources and a compensatory mechanism. In fact, obstacles to climate negotiations are elsewhere. Developed countries must assume their historical responsibilities in climate change through an effective constraining commitment to limit emissions at the national level, which entails important internal transformations to achieve energy transition effectively. While they expect commitment to mandatory targets from other countries (reduction goals, as well as Measuring, Reporting and Verification (MRV)), ${ }^{41}$ they should respond to demands from developing and some emerging economies for financing, technology transfer, and sobriety policies. Such requirements could be accommodated through the implementation of a global carbon price, as requested by NGOs and international organizations. BCAs would be useful in achieving such global dispositive, by balancing environmental efforts with growing equity. Difficulties in implementation, which appear to be more of an economic nature than legal or political, can be overcome. The French proposal to apply BCAs according to the global GHG emissions volume per capita or per unit of GDP, rather than the amount of carbon contained in a product, seems to be not only feasible, but also fair since calculation will be favourable to developing countries. BCA implementation requires, nevertheless, a strong and durable political commitment to environmental protection and its design calls for a careful assessment of the numerous constraints exposed earlier in this paper.

\section{References}

Association NégaWatts (2011). 'Manifeste NégaWatts, Domaine du possible'. France: Actes Sud/Colibris/Association NégaWatt.

Blanchard, O., P. Criqui, A. Kitous, and S. Mima (2006). 'The impact of climate policies on energy markets and the price of carbon'. Revue d'économie financière (English ed.), Carbon Finance, 83: 89-110.

Böhringer, C., E.J. Balistreri, and T.F. Rutherford (2012). 'The role of border carbon adjustment in unilateral climate policy: results from EMF 29'. Energy Economics, 34: 97-110.

\footnotetext{
40 Transformations will be driven by climate changes. Modifications carried out in a hurry will be less efficient than more carefully prepared and designed lifestyle and behavioural changes.

${ }^{41} \mathrm{MRV}$ is a term used to describe all measures taken by States to collect data on emissions, mitigation actions, and support, to compile this information in reports and inventories, and to subject these to some form of international review or analysis.
} 
Branger, F., P. Quirion, and J. Chevallier (2013). 'Carbon leakage and competitiveness of cement and steel industries under the EU ETS: much ado about nothing'. Cired Working Paper 532013. Paris: Cired.

Bueb, J. (2014). 'Marché de quotas d'émission négociables ou taxe carbone? Un enjeu en termes d'efficacité'. IHEJ.

Cosbey, A. (2008). 'Trade and climate change: issues in perspective'. Final Report and Synthesis Discussions, Trade and Climate Change Seminar, Copenhagen, 18-20 June 2008.

Demailly, D., and P. Quirion (2008). 'Concilier compétitivité industrielle et politique climatique: faut-il distribuer les quotas de $\mathrm{CO} 2$ en fonction de la production ou bien les ajuster aux frontières?'. La Revue Économique, 59(3): 497-504.

Dröge, S., H. van Hasselt, T. Brewer, M. Grubb, R. Ismer, Y. Kameyama et al. (2009). 'Tackling leakage in a world of unequal carbon prices'. Rapport de synthèse, Climate Strategies. Cambridge: Royaume-Uni.

France (2009). 'LOI no 2009-967 du 3 août 2009 de programmation relative à la mise en œuvre du Grenelle de l'environnement'. JORF nº 0179 du 5 août 2009 page 13031, texte $n^{\circ} 2$. Available at: https://www.legifrance.gouv.fr/eli/loi/2009/8/3/DEVX0811607L/jo/texte (accessed 21 March 2016).

GATT (1947). The General Agreement on Tarifs and Trade. Available at: https://www.wto.org/english/docs_e/legal_e/gatt47_01_e.htm (accessed 14 March 2016).

Giraud, G., and Z. Kahraman (2014). 'How dependent is growth from primary energy?'. CNRS Working Paper. France: CNRS.

Houser, T., R. Bradley, B. Childs, J. Werksman, and R. Heilmayr (2008). 'Leveling the carbon playing field: International competition and US climate policy design'. Washington, DC: Peterson Institute for International Economics and World Resources Institute. Available at: http://pdf.wri.org/leveling_the_carbon_playing_field.pdf (accessed 11 March 2016).

IPCC (2014). 'Climate change 2014: Synthesis report'. Contribution of Working Groups I, II, and III to the Fifth Assessment Report of the Intergovernmental Panel on Climate Change. Geneva: IPCC.

Ireland, R. (2010). 'Implications for customs of climate change mitigation and adaptation policy options: a preliminary examination'. World Customs Journal, 4(2).

Keucheyan, R. (2014). 'La nature est un champ de bataille'. Essai d'écologie politique. Paris: Zones, La Découverte.

Laurent, E. (2011). Social écologie. Paris: Flammarion.

Markusen, J.R. (1975). 'International externalities and optimal tax structures'. Journal of International Economics, 5(1): 15-29.

Mattoo, A., and A. Subramanian (2013). 'Greenprint: A new approach to cooperation on climate change’. Washington, DC: Center for Global Development.

Monjon, S., and P. Quirion (2010). 'How to design a border adjustment for the European Trading System’. Energy Policy. doi:10.1016/j.enpol.2010.05.005.

Morosini, F. (2010). 'Trade and climate change: Unveiling the principle of common but differentiated responsibilities from the W'TO agreements'. George W ashington International Law Review, 42(4): 717-25. 
OECD Trade and Agriculture Directorate and Environment Directorate (2014). 'Border carbon adjustment and international trade: a literature review'. Joint Working Party on Trade and Environment, COM/TAD/ENV/JWPTE(2014)51/FINAL. Paris: OECD.

Pearce, J.M. (2009). 'Optimizing greenhouse gas mitigation strategies to suppress energy cannibalism'. Second conference on climate change technologies, Hamilton, Ontario, Canada.

Rayner, S. (2010). 'How to eat an elephant: A bottom-up approach to climate policy'. Climate Policy, 10(6): 615-21.

Richieri Hanania, L. (2009). 'Diversité culturelle et droit international du commerce'. Paris: CERIC, La Documentation française.

Roman, P. (2014). 'Le découplage PIB-matières'. In T. Caminel, G. Giraud, P. Frémeaux, A. Lalucq, and P. Roman (2014). Produire Plus, Polluer Moins: l'Impossible Découplage?. Paris: Les Petits Matins.

Ruiz Fabri, H. (2007). 'La nécessité devant le juge de l'OMC'. Le droit international et la nécessité, Paris: SFDI, Pedone, pp 189-221.

Schott J.J., and M. Fickling (2010), 'Revisiting the NAFTA agenda on climate change'. Peter G. Peterson Institute for International Economics, PB 10-19. Available at: http://www.piie.com/publications/pb/pb10-19.pdf (accessed 22 March 2016).

Stiglitz, J.E. (2006). 'A new agenda for global warming'. Economists' Voice, 3(7).

Tubiana L. (1991). 'La mondialisation contre l'écologie'. Le Monde diplomatique. Available at: http://www.monde-diplomatique.fr/1991/01/TUBIANA/43229 (accessed 11 March 2016).

United Nations (UN) (1992). 'Rio Declaration on Environment and Development'. Report of the United Nations Conference on Environment and Development, Rio de Janeiro, 3-14 June 1992, Annex I. Available at: http://www.un.org/documents/ga/conf151/aconf151261annex1.htm (accessed 14 March 2016).

UNDP (2011). Human Development Report 2011. Sustainability and equity: A better future for all. Available

at: http://hdr.undp.org/sites/default/files/reports/271/hdr_2011_en_complete.pdf (accessed 14 March 2016).

Weber, C.L., and G.P. Peters (2009). 'Climate change policy and international trade: Policy considerations in the US'. Energy Policy, 37: 432-40.

World Trade Organization (WTO) (1994). 'Marrakesh Agreement establishing the World Trade Organization’. Available at: https://www.wto.org/english/docs_e/legal_e/04-wto_e.htm (accessed 14 March 2016).

World Trade Organization (WTO) (1996a). 'Appellate body report, Japan-Taxes on alcoholic beverages’. WT/DS8/AB/R; WT/DS10/AB/R; WT/DS11/AB/R. Geneva: World Trade Organization.

World Trade Organization (WTO) (1996b). 'Appellate body report, United States-Standards for reformulated and conventional gasoline'. WT/DS2/AB/R. Geneva: World Trade Organization.

World Trade Organization (WTO) (1998a). 'Appellate body report, European CommunitiesMeasures concerning meat and meat products (hormones)'. WT/DS26/AB/R and W'T/DS48/AB/R. Geneva: World Trade Organization. 
World Trade Organization (WTO) (1998b). 'Appellate body report, United States-Import prohibition of certain shrimp and shrimp products'. WT/DS58/AB/R. Geneva: World Trade Organization.

World Trade Organization (WTO) (2000). 'Appellate body report, Korea-Measures affecting imports of fresh, chilled and frozen beef. WT/DS161/AB/R and WT/DS169/AB/R. Geneva: World Trade Organization.

World Trade Organization (WTO) (2004). 'Appellate body report, European communitiesConditions for the granting of tariff preferences to developing countries'. WT/DS246/AB/R. Geneva: World Trade Organization.

World Trade Organization (WTO) (2015). 'Special and differential treatment provisions'. Geneva: World Trade Organization. Available at: https://www.wto.org/english/tratop_e/devel_e/dev_special_differential_provisions_e.htm (accessed 16 September 2015).

WTO-UNEP (2009). 'Trade and climate change'. Joint report by the United Nations Environment Programme and the World Trade Organization. Available at: https://www.wto.org/english/res_e/booksp_e/trade_climate_change_e.pdf (accessed 16 September 2015).

Zhang, Z.X. (2010). 'Climate change meets trade in promoting green growth: Potential conflicts and synergies'. Fondazione Eni Enrico Mattei Working Papers 408. Venice: FEEM. 